Article

\title{
Acute Effects of the Consumption of Passiflora setacea Juice on Metabolic Risk Factors and Gene Expression Profile in Humans
}

\author{
Isabella de Araújo Esteves Duarte ${ }^{1, *(1)}$, Dragan Milenkovic ${ }^{2,3(0)}$, \\ Tatiana Karla dos Santos Borges ${ }^{4}$, Artur Jordão de Magalhães Rosa ${ }^{5}\left(D\right.$, Christine Morand ${ }^{2}$, \\ Livia de Lacerda de Oliveira ${ }^{1}$ and Ana Maria Costa ${ }^{5}$ \\ 1 Postgraduate Program in Human Nutrition, College of Health Sciences, Campus Universitário Darcy \\ Ribeiro, Universidade de Brasília, Brasília DF 70.910-900, Brazil; liviadelacerda@gmail.com \\ 2 Unité de Nutrition Humaine, Université Clermont Auvergne, INRAE, UNH, F-63000 Clermont-Ferrand, \\ France; dragan.milenkovic@inra.fr (D.M.); christine.morand@inra.fr (C.M.) \\ 3 Department of Internal Medicine, Division of Cardiovascular Medicine, School of Medicine, \\ University of California Davis, Davis, CA 95616, USA \\ 4 Laboratory of Cellular Immunology, Faculty of Medicine, University of Brasilia, Brasilia DF 70.910-900, \\ Brazil; tatianakarlab@gmail.com \\ 5 Laboratory of Food Science, Embrapa Cerrados, Planaltina DF 73.310-970, Brazil; \\ artur.rosa@embrapa.br (A.J.d.M.R.); ana-maria.costa@embrapa.br (A.M.C.) \\ * Correspondence: duarte.isabella07@gmail.com; Tel.: +55-61-99996-8004
}

Received: 14 March 2020; Accepted: 31 March 2020; Published: 16 April 2020

check for updates

\begin{abstract}
Background: Passiflora setacea (PS) is a passionfruit variety of the Brazilian savannah and is a rich source of plant food bioactives with potential anti-inflammatory activity. This study aimed to investigate the effect of an acute intake of PS juice upon inflammation, metabolic parameters, and gene expression on circulating immune cells in humans. Methods: Overweight male volunteers $(n=12)$ were enrolled in two double-blind placebo-controlled studies. Blood samples were collected from fasting volunteers $3 \mathrm{~h}$ after the consumption of $250 \mathrm{~mL}$ of PS juice or placebo (PB). Metabolic parameters (insulin, glucose, total cholesterol, high-density lipoprotein (LDL), high-density lipoprotein (HDL), and total triglycerides) and circulating cytokines were evaluated (study 1). Peripheral blood mononuclear cell (PBMC) from the same subjects were isolated and RNA was extracted for transcriptomic analyses using microarrays (study 2). Results: Insulin and homeostatic model assessment for insulin resistance (HOMA-IR) levels decreased statistically after the PS juice intake, whereas HDL level increased significantly. Interleukin (IL)-17A level increased after placebo consumption, whereas its level remained unchanged after PS juice consumption. Nutrigenomic analyses revealed 1327 differentially expressed genes after PS consumption, with modulated genes involved in processes such as inflammation, cell adhesion, or cytokine-cytokine receptor. Conclusion: Taken together, these clinical results support the hypothesis that PS consumption may help the prevention of cardiometabolic diseases.
\end{abstract}

Keywords: Passiflora setacea; bioactive compounds; phenolic compounds; cardiovascular diseases; nutrigenomics; gene expression; immune system; cytokines; insulin; HDL

\section{Introduction}

According to the World Health Organization (WHO), noncommunicable diseases (NCDs) are responsible for $71 \%$ of deaths worldwide, leading to the death of 15 million people aged between 30 and 69 years old. The most prevalent diseases are cardiovascular diseases, followed by cancers, respiratory 
diseases, and diabetes [1]. At the same time, the total number of people suffering from depression or other common mental disorders such as anxiety was estimated as exceeding 300 million people in 2015. These disorders are the biggest contributors to global disability and represent an important cost burden [2]. Therefore, stressful lifestyle markers such as emotional stress, an unhealthy diet (high in sugar, sodium, red meat, and trans fatty acids, but low intake of fruits and vegetables), overweight [3], and poor physical activity [4] increase the incidence of cardiovascular diseases (CVD) and NCDs. These lifestyle risk factors promote high blood pressure, hyperglycemia, hyperinsulinemia, hypertension, hyperlipidemia [1,5], obesity [1], high inflammatory cytokine production [6], and pro-atherogenic gene profile [7], and are associated with chronic low-grade inflammation and vascular inflammation [8].

A higher intake of fruit and vegetables is associated with a lower risk of all causes of mortality, particularly inflammation-related diseases [9]. Plant-based foods are sources of a variety of bioactive compounds (BC) such as terpenoids (carotenoids, essential oil components, phytosterols), polyphenols (flavonoids and non-flavonoids compounds) [10], sulfur compounds (glucosinolates and ally sulfinates), alkaloids [11], and polyamines [12], whose level of total intake is connected with the protection from chronic diseases, including cardiovascular diseases, cancers, and neurodegenerative diseases [11,12]. Several beneficial effects have been related to the consumption of these compounds such as antioxidant and anti-inflammatory activities [12,13]. These beneficial effects derive from the reported capacity of some BC to modulate cell signaling and consequently the expression of key genes [14]. The species of Passiflora genus have been studied due to their sedative, anxiolytic, anti-inflammatory, antioxidant, and anti-carcinogenic effects $[15,16]$. Passiflora setacea D.C (PS) is a wild passionfruit species of the Brazilian savannah, popularly known as "maracujá do sono" ("sleep passionfruit"). The consumption of these fruits has been traditionally associated with sleep modulation [17]. PS pulp and seeds have recently been identified as rich in BC, particularly in C-glycosides of flavonoids [18], and also homoorientin, vitexin, isovitexin, and orientin at higher contents than those found in Passiflora edulis, açaí (Eurydema oleracea), and orange juice [19]. They have also revealed antioxidant and antimicrobial properties in vitro $[20,21]$. These effects are potentially due to the presence of vitamin $\mathrm{E}$ and $\mathrm{BC}$ such as terpenoids, polyamines, and polyphenols, especially orientin, isoorientin, vitexin, and isovitexin [17-19,21]. These compounds have been reported to exert antioxidant, anti-inflammatory, vascular, neuroprotective, anxiolytic, and antidepressant-like effects [22-26]. Plant-based diets are recognized for their beneficial effects on the modulation of intermediate risk factors for inflammation-based disorders [27,28], and fruits constitute major contributors to these effects [29]. However, clinical studies focusing on the health properties of fruits of the Brazilian savannah, as well as on the potential underlying molecular mechanisms, including the modulation of expression of genes in humans, remain scarce. Therefore, the aim of our study was to evaluate the effect of acute consumption of PS pulp on metabolic and inflammatory biomarkers in overweight male volunteers, as well as to assess the impact on global gene expression profile in peripheral blood mononuclear cell (PBMC) by using microarray analyses.

\section{Materials and Methods}

\subsection{Processing and Characteristics of Passiflora setacea Juice}

The fruit used in this study was the PS, the BRS Pérola do Cerrado (BRS Pearl of the Brazilian savannah), which is cultivated at the experimental field of Embrapa Cerrados, Brasilia, Brazil, affiliated with the Brazilian Ministry of Agriculture. This study is part of a larger program called the Passitec Network, developed to improve fruit size and production. PS plants were cultivated in a vertical espalier system and the ripe fruits were harvested at their full maturity level during the rainy season, corresponding to the stage where the phenolics compounds were in their highest concentrations [19].

The pulps used in this experiment were prepared all at once and were aliquoted, thus allowing us to use the same batch of pulp throughout the study. The pulps were removed from the fruits and blended for $30 \mathrm{~s}$ to separate the seeds from the pulps by sieving. After that, they were aliquoted into 
portions of $150 \mathrm{~g}$ and placed into plastic bags, hermetically sealed, and stored at $-80{ }^{\circ} \mathrm{C}$. The batch of pulp used in this study contained $2.75 \mathrm{~g} / 100 \mathrm{~g}$ in fresh weight (FW) of carbohydrates, $10.1 \mathrm{mg} / 100 \mathrm{~g}$ FW of vitamin C, $55.4 \mathrm{mg} / 100 \mathrm{~g}$ of proanthocyanidins, $86 \mathrm{mg}$ gallic acid equivalents (GAE)/100 $\mathrm{g}$ FW of total phenolics, and $3.02 \mathrm{mg}$ quercetine equivalents $(\mathrm{QE}) / 100 \mathrm{~g} \mathrm{FW}$ of total flavonoids in which we have results for the four main flavone C-glycosides $(1.07 \mathrm{mg} / \mathrm{g}$ dry weight (DW) of orientin, $0.99 \mathrm{mg} / \mathrm{g}$ DW of isoorientin, $0.84 \mathrm{mg} / \mathrm{g}$ DW of vitexin, $1.13 \mathrm{mg} / \mathrm{g}$ DW of isovitexin) and for the flavanone glycoside (0.14 $\mathrm{mg} \mathrm{g}^{-1} \mathrm{FW}$ of hesperetin equivalent) [19]. The isocaloric placebo drink (PB) was obtained by mixing $100 \mathrm{~mL}$ of a passionfruit-flavored isotonic drink of the brand Gatorade with $150 \mathrm{~mL}$ of water to achieve the same final volume and sugar content of the PS juice (List S1).

\subsection{Subjects and Study Design}

Male volunteers $(n=12)$ were recruited by interviews after advertisements were published in the media (newspaper, website, etc.) from February to June 2015. Men, ranging from 40 to 64 years old, who were overweight or slightly obese (based on body mass index (BMI) between 25 and $31 \mathrm{~kg} / \mathrm{m}^{2}$ or waist circumference $>94 \mathrm{~cm})$, non-smokers, and engaged in a low to moderate level $(<5 \mathrm{~h} /$ week $)$ of physical activity were eligible for inclusion. The exclusion criteria included a medical history of cancer or severe metabolic diseases, special dietary habits (e.g., vegetarians and vegans), use of dietary supplementation 2 months prior to the experiment (vitamin C, multivitamin, antioxidant capsules, etc.), chronic medication (anti-hypertensives, anti-hyperglycemic, anti-cholesterol, anti-depressants, anxiolytics, etc.), acute treatments 15 days prior to the experiment (anti-inflammatory drugs, antibiotics, etc.), and acute treatments 2 days prior to the experiment (inflammatory pain relievers such as aspirin, acetaminophen, etc.). A physical evaluation was performed to obtain measurements of weight, BMI, waist circumference, and percentage of body weight by applying the seven skinfold sites Jackson-Pollock method [30].

The study was performed in two phases. In both phases, the volunteers were asked to consume a "white meal", which is a meal without foods rich in BC (vegetables, fruits, cocoa, and plant-based drinks) the day before the experiment (Table S1). Seventy-two hours before the experiment, volunteers were asked not to consume alcohol or perform any kind of intense physical activity such as cycling and running. Study phase 1 aimed to set a controlled environment in which all volunteers would be offered the same food menu at the same time. For this, the volunteers $(n=12)$ were hosted for 2 days in a hotel. At day 1, blood samples were collected at fasting (T0) and $3 \mathrm{~h}$ after (T3) the consumption of $250 \mathrm{~mL}$ of placebo drink (PB). Similarly, on day 2, blood samples were collected at fasting and $3 \mathrm{~h}$ after the consumption of $250 \mathrm{~mL}$ of PS juice. Blood sampling and further biochemical analyses were performed by the Sabin clinical analysis laboratory, Brasilia. The results of the data obtained in study phase 1 are reported in Sections 3.2 and 3.3.

After the first intervention, the study phase 2 aimed to investigate the effect of the consumption of PS juice on gene expression in the volunteers. The same volunteers were asked to consume the same "white meal" as in study phase 1 (Table S1). The volunteers were invited to participate in a randomized crossover trial in which they had to acutely consume the same two beverages ( $250 \mathrm{~mL}$ PB or PS) in an interval of a 10-day washout period for the nutrigenomic study. This phase was performed at the Laboratory of Cellular Immunology, Faculty of Medicine, University of Brasilia, Brasilia. The results of the data obtained in study phase 2 are reported in Sections 3.4-3.6. For each experimental period, the fasting volunteers consumed either $250 \mathrm{~mL}$ of placebo drink (PB) or of P. setacea (PS) at the moment of their arrival in the morning, and blood samples were collected $3 \mathrm{~h}$ later.

This study was performed with the approval of the National Health Research Ethics Committee (CONEP, Brasilia, Brazil), protocol number 36348114.3.0000.0030, and all the volunteers provided their written informed consent. Description of the study can be found on ensaiosclinicos.gov.br RBR-84z83n. 


\subsection{Blood Sampling and Treatment}

From the blood sampled in study phase 1 , serum and plasma fractions were prepared to quantify metabolic markers (including glucose, insulin, homeostasis model assessment of $\beta$-cell function (HOMA-BETA), homeostatic model assessment for insulin resistance (HOMA-IR), total cholesterol, high-density lipoprotein (HDL), low-density lipoproteins (LDL) and total triglycerides) and cytokines. The collection of biological samples and the biochemical analysis were conducted by Sabin laboratory on the same day. Blood sampling was also collected in heparin tubes and stored at $-80^{\circ} \mathrm{C}$ for the later quantification of cytokines. In study phase 2 (Laboratory of Cellular Immunology), blood samples were collected in heparin tubes for further nutrigenomics analysis on isolated PBMC. A total of $8 \mathrm{~mL}$ of venous blood was collected from volunteers using BD Vacutainer tubes (Becton Dickinson, Franklin Lakes, NJ, USA), and PBMCs were isolated. Briefly, the tubes were immediately centrifuged at room temperature for $20 \mathrm{~min}$ at $1500 \times \mathrm{g}$. After centrifugation, the cell layer containing PBMCs was collected and washed twice with sterile phosphate-buffered saline (PBS) with centrifugation at $300 \times g$ for $10 \mathrm{~min}$ after each washing step. The cell pellet obtained was immediately frozen at $-80{ }^{\circ} \mathrm{C}$ and kept at this temperature until use.

\subsection{Biochemical Parameters and Cytokines Analysis}

The biochemical analyzes were conducted by Sabin Laboratory, Brasilia. To evaluate glucose, the hexokinase method was used; as for insulin, the insulin chemiluminescent immunoassay was applied, then HOMA BETA and HOMA IR were calculated. Total cholesterol was verified by means of the Allain's method of esterase/oxidase [31], HDL by using the direct method, LDL through the Martin-Hopkins's calculation, and total triglycerides by means of the oxidase/peroxidase method.

To quantify the circulating cytokines, serum samples were used to measure interleukin-2 (IL-2), interleukin-4 (IL-4), interleukin-6 (IL-6), interleukin-10 (IL-10), tumor necrosis factor (TNF), interferon- $\gamma$ (INF- $\gamma$ ), and interleukin-17 (IL-17) protein levels by using the CBA Human T-cell TH1/TH2/TH17 Cytokine kit (Becton Dickinson, Franklin Lakes, NJ, USA). This method used bead array technology to simultaneously detect multiple cytokine proteins in the samples by flow cytometry. All the analyses were executed according to the manufacturer's guidelines. Shortly, cytokine capture beads were mixed with the plasma samples and incubated with phycoerythrin (PE)-conjugated detection antibodies to form sandwich complexes. The FCAP Array software was used to generate results in graphical and tubular format.

\subsection{Total RNA Extraction}

Total RNA extraction from PBMC was performed by using RNeasy Mini Kit, as recommended by the manufacturer (Qiagen, Hilden, Germany). The RNA quality was checked by means of $1 \%$ agarose gel electrophoresis, whereas the quantity was checked through absorbencies at 260 and $280 \mathrm{~nm}$ on NanoDrop ND-1000 spectrophotometer (Thermo Scientific, Wilmington, DE, USA). The RNA samples were stored at $-80^{\circ} \mathrm{C}$ until use.

\subsection{Microarray Analyses and Bioinformatic Analysis}

Total RNA (50 ng per sample) was amplified and fluorescently labeled to produce Cy5 or Cy3 complementary RNA (cRNA) by using the Low Input Quick Amp Labeling Two-Color Kit (Agilent, Santa Clara, CA, USA) in the presence of a two-color spike-in control, as recommended by the manufacturer. After purification, $825 \mathrm{ng}$ of labeled cRNA was hybridized onto G4845A Human GE 4x44K v2 microarray (Agilent, Santa Clara, CA, USA) according to the manufacturer's instructions. The G4845A Human GE 4x44K v2 microarray contains 27,958 Entrez Gene RNA sequences. After hybridization, an Agilent G2505 scanner (Agilent, Santa Clara, CA, USA) was used to scan microarrays. The hybridization data were extracted by means of the Feature Extraction software version 11.0 and analyzed through the GeneSpring GX software version 14.5 (Agilent Technologies, Santa Clara, CA, USA). Data were normalized using 50th percentile shift and analyzed with moderated $t$-tests 
corrected by Westfall-Young permutation with corrected $p$-value cut-off set to 0.05 . All transcripts presenting $p<0.05$ were considered differently expressed.

\subsection{Bioinformatic Analyzes}

For biological interpretation of the differentially expressed genes, we first performed Gene Ontology (GO) analyses using DAVID (Database for Annotation, Visualization and Integrated Discovery v6.7). The GO results were grouped on the basis of their functionality by using the online REVIGO software. The partial least squares discriminant analysis (PLSDA) plot was obtained through MetaboAnalyst (https://www.metaboanalyst.ca). Gene networks were built with a data-mining approach using the Metacore software, and gene pathway analyses of the Kyoto Encyclopedia of Genes and Genomes (KEGG) and BioCarta databases were conducted by using the Genetrial2 online tool.

\subsection{Statistical Analyses}

The data obtained were previously analyzed for normality through D'Agostino's and Pearson's tests. The outlier values were calculated by means of the Tukey test and excluded from the analyses only when interfering with normality values. For two independent groups, paired Student's $t$-test was applied to samples that had a normal distribution, and for those without normal distribution, Wilcoxon's $t$-student test was applied. Descriptive values were expressed as mean $\pm \mathrm{SD}$ corrected. The differences between the variables compared were considered statistically significant when the bi-tailed probability of their occurrence due to chance (type I error) was less than $5 \%(p<0.05)$. Analyses and graphs were performed by using the GraphPad Prism 7 software for Mac (GraphPad Software, San Diego, CA, USA).

\section{Results}

\subsection{Volunteers' Baseline Characteristics}

The baseline characteristics of the volunteers are summarized in Table 1. The subjects enrolled were men with a mean age of $48.66 \pm 6.82$ years that were overweight or slightly obese (BMI ranging from 25.00 to 30.80) with a mean waist circumference of $96.83 \pm 6.49 \mathrm{~cm}$. The subjects ranged from normal to slightly hyperglycemic $(n=1,103 \mathrm{mg} / \mathrm{dL})$, as well as from normal to mildly hyperlipidemic $(n=2)$, as shown by the values for plasma total triglycerides (Table 1$)$. All the other parameters were within normal range. Two of the 12 volunteers presented three to four factors that may define them as having a metabolic syndrome (waist circumference $\geq 90 \mathrm{~cm}$; serum triglycerides $\geq 150 \mathrm{mg} / \mathrm{dL} \mathrm{mmol} / \mathrm{l}$; HDL cholesterol $<40 \mathrm{mg} / \mathrm{dL}$; and fasting plasma glucose (FPG) $\geq 100 \mathrm{mg} / \mathrm{dL}$ ). Statistical tests without these volunteers were therefore remade and the statistical significances did not change.

Table 1. Volunteers' baseline characteristics $(n=12)$.

\begin{tabular}{cc}
\hline Parameter & Mean \pm SD (Range) \\
\hline Age, years & $48.66 \pm 6.82(41-62)$ \\
BMI, $\mathrm{kg} / \mathrm{m}^{2}$ & $28.18 \pm 2.08(25.0-30.8)$ \\
Waist circumference, cm & $96.83 \pm 6.49(88-112)$ \\
Fasting glucose, $\mathrm{mg} / \mathrm{dL}$ & $90.83 \pm 5.54(83-103)$ \\
Basal insulin, $\mu \mathrm{UI} / \mathrm{mL}$ & $11.14 \pm 3.58(5.5-17.7)$ \\
HOMA IR & $2.49 \pm 0.77(1.2-3.7)$ \\
HOMA BETA & $152.8 \pm 71.58(73-304)$ \\
Triglycerides, mg/dL & $116.58 \pm 57.55(49-218)$ \\
Total cholesterol, mg/dL & $188.17 \pm 33.40(115-232)$ \\
HDL cholesterol, mg/dL & $47.91 \pm 10.67(38-72)$ \\
LDL cholesterol, mg/dL & $117.00 \pm 27.09(60-156)$ \\
Apoliprotein A, mg/dL & $133.67 \pm 20.95(107-172)$ \\
Apoliprotein B, mg/dL & $101.77 \pm 24.80(49-133)$ \\
Creatinin, $\mathrm{mg} / \mathrm{dL}$ & $0.97 \pm 0.14(0.7-1.2)$ \\
TGO, U/L & $20.67 \pm 2.87(14-25)$ \\
TGP, U/L & $25.41 \pm 6.97(11-35)$ \\
\hline
\end{tabular}




\subsection{Effect of Passiflora setacea Juice on Glucose and Lipid Metabolism (Phase 1)}

Glucose, insulin, HOMA IR, triglycerides and HDL in plasma were analyzed before (T0) and $3 \mathrm{~h}$ after (T3) the intake of placebo and PS juice. The data show that insulin and HOMA IR levels decreased statistically $3 \mathrm{~h}$ after PS juice intake ( $p=0.0068$ and $p=0.001$, respectively), whereas no significant change was observed after the placebo intake (Figure 1A). The plasma glucose concentrations decreased in a similar way after the intake of the two drinks. The high-density lipoprotein (HDL) level increased significantly after PS juice consumption $(p=0.0280)$, whereas no change was observed after PB drink $(p=0.3541)$, as seen in Figure 1B. No effects of PS or PB were detected on total and LDL cholesterol levels.

A
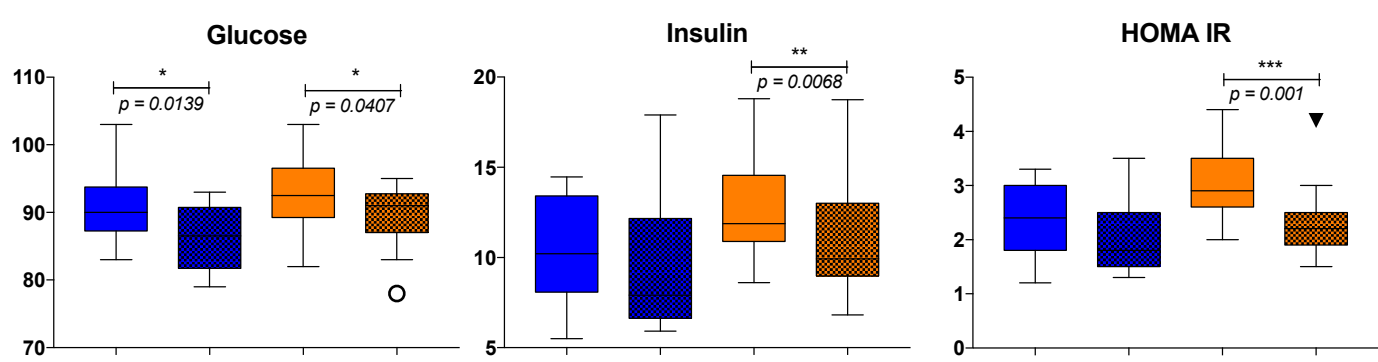

B
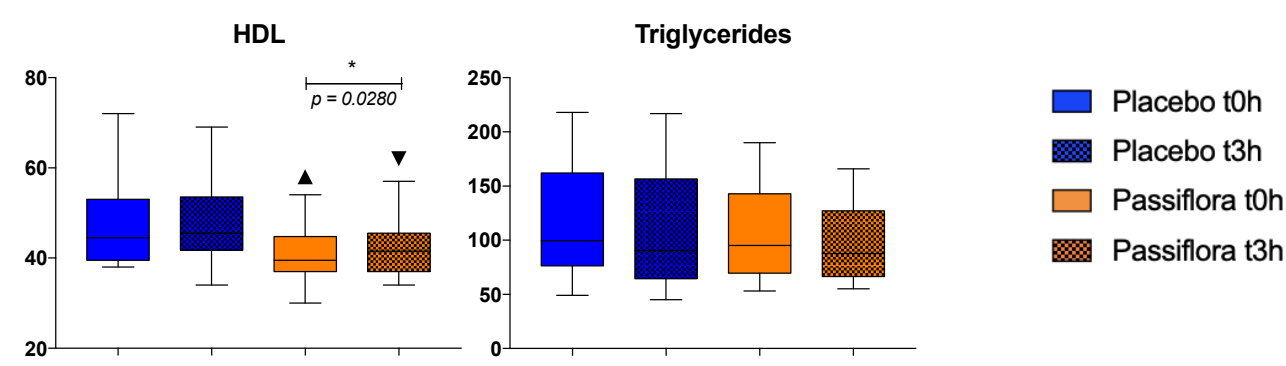

Figure 1. Acute effect of Passiflora setacea juice and placebo drink consumption on glucose (A) and lipid (B) metabolism markers in overweight volunteers $(n=12)$. Results analyzed by means of the non-parametric paired $t$-test (Wilcoxon's test), medians, and SD. ${ }^{*} p \leq 0.05,{ }^{* *} p \leq 0.01,{ }^{* * *} p \leq 0.001$.

\subsection{Effect of Passiflora setacea Juice Intake on Cytokine Serum Levels (Phase 1)}

We determined the effect of PS juice intake on cytokine serum levels. Data showed that the IL-17A level did not increase after $3 \mathrm{~h}$ of PS juice consumption ( $p=0.2962)$; however, it increased after placebo consumption ( $p=0.0124$ ) (Figure 2$)$. We also observed that TNF- $\alpha$ presented a similar but not significant pattern as IL-17A, that is, its level tended to increase after PB drink $(p=0.0645)$, whereas it remained unchanged after PS juice $(p=0.5489)$ (Figure 2$)$. There were no statistical changes in the other cytokine measures of IL-2, IL-4, IL-6, IL-10, and INF- $\gamma$ (Figure 2).

\subsection{Passiflora setacea Modulated Gene Expression in Circulating Cells (Phase 2)}

Following RNA extraction and quality control of both RNA and microarray hybridization, we obtained good quality RNA from 8 out of 12 volunteers. To access the nutrigenomic effect of an acute intake of PS juice in PBMCs, we performed a pangenomic gene expression analysis $3 \mathrm{~h}$ after PS juice and PB drink consumption for the eight volunteers. Comparison of global gene expression profiles obtained for the volunteers by using PLSDA showed the separation of profiles between the two groups, suggesting different gene expression profiles between the volunteers that consumed PS and the volunteers that consumed PB (Figure 3). This observation suggests differential modulation in expression of genes after an acute intake of PS juice compared to the control drink. 
IL-17A

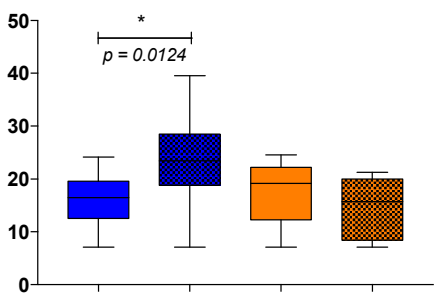

IL-10

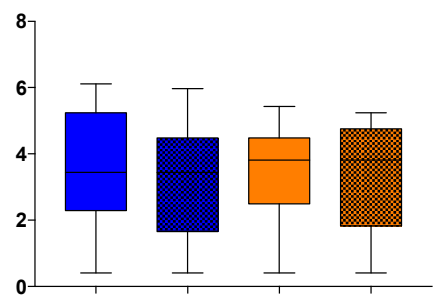

INF-Y

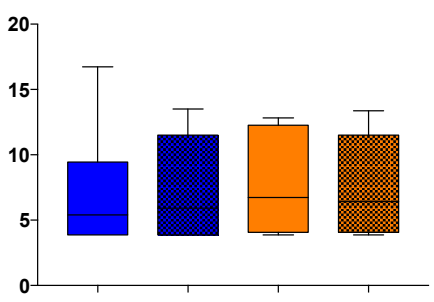

IL-6

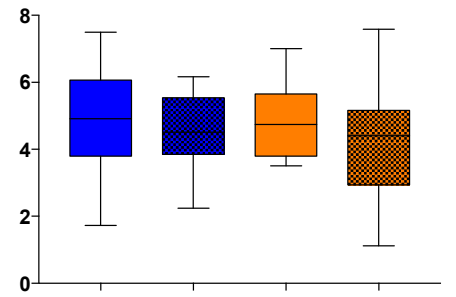

IL-2

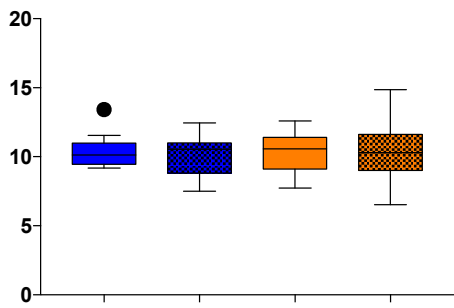

TNF- $\alpha$

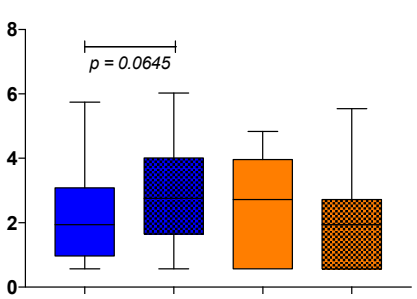

IL-4

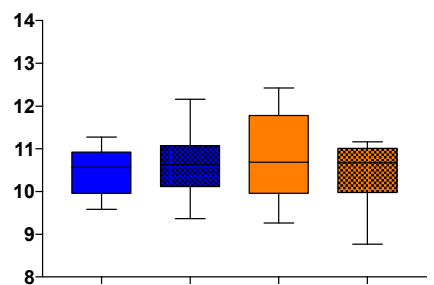

$\square$ Placebo t0h

Placebo $3 \mathrm{~h}$

$\square$ Passiflora toh

Passiflora $\mathrm{t} 3 \mathrm{~h}$

Figure 2. Acute effect of Passiflora setacea juice consumption on cytokine serum levels in overweight volunteers $(n=12)$. Results analyzed by means of the non-parametric paired $t$-test (Wilcoxon's test). * $p \leq 0.05, \bullet$ outlier tested by Tukey.

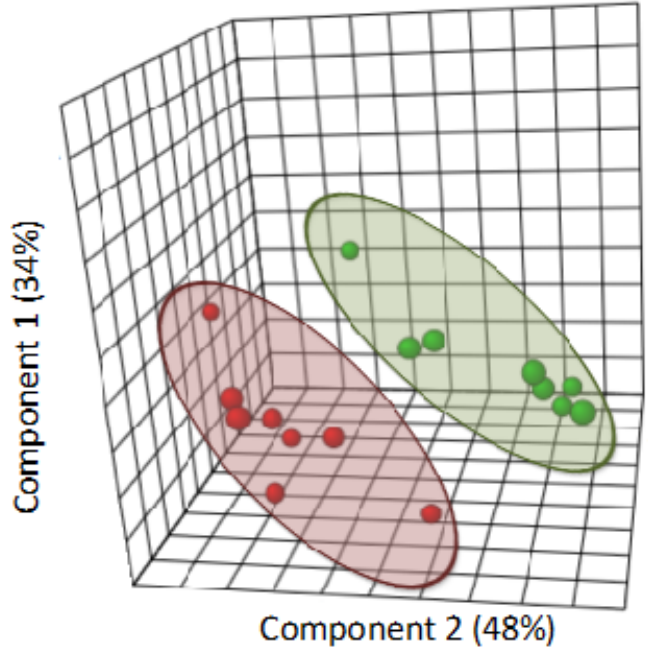

Figure 3. The comparison of the global gene expression profiles obtained for the volunteers using partial least squares discriminant analysis (PLSDA) shows the separation of profiles between the two groups, and suggests different gene expression profiles between the volunteers that consumed Passiflora setacea juice (PF) and the volunteers that consumed placebo (PB; placebo).

Following this observation, we performed a statistical analysis to identify which genes had their expression altered after the consumption of PS compared to PB. Statistical analyses identified 1327 genes presenting changes in their expression after PS consumption. Among them, most genes were identified as having their expression down-regulated with the average fold-change for up-regulated genes being 
2.48 and for down-regulated genes being -2.15 . Among the genes showing the highest differential modifications were TMEM151A, MLPH, MYH2, SERPINA9, or FNA21.

For the biological interpretation of the differentially expressed genes, we first performed Gene Ontology (GO) analyses using DAVID database, and the GO were then clustered into function groups by using the online REVIGO software. This showed that differentially expressed genes are involved in various biological processes such as calcium ion transmembrane transport (potassium ion transport and phospholipid efflux), cell differentiation (extracelular matrix organization and histone lysine methylation), G-protein-coupled receptor signaling pathway (chemical synaptic transmission and neuropeptide signaling pathway), cell adhesion, and transcription from RNA polymerase promoter (Figure S1). This analysis revealed that the consumption of PS juice modulated the expression of genes presenting different biological functions.

To deepen the identification of the functions and cellular processes potentially affected by the consumption of PS juice, we performed gene network analyses of the differentially expressed genes. Gene networks, built through data-mining using the Metacore software, suggested, as did the GO analyses, that the consumption of PS juice changed the expression of genes involved in cellular function. Among the most over-represented networks were those involved in calcium and potassium transport, cell adhesion and cell-matrix interactions, neurogenesis, or transmission of nerve impulse (Figure 4). The genes identified in these networks were NMDA receptor, matrix metalloproteinase (MMP)-7, ADAMTS9, mGluR, CaMKII alpha, CACNA1C, and SLC24A2. These genes decode proteins involved in vascular tissue damage, in the reduction of insulin sensitivity and secretion, and in neuropsychiatric disorders and neuron excitability.

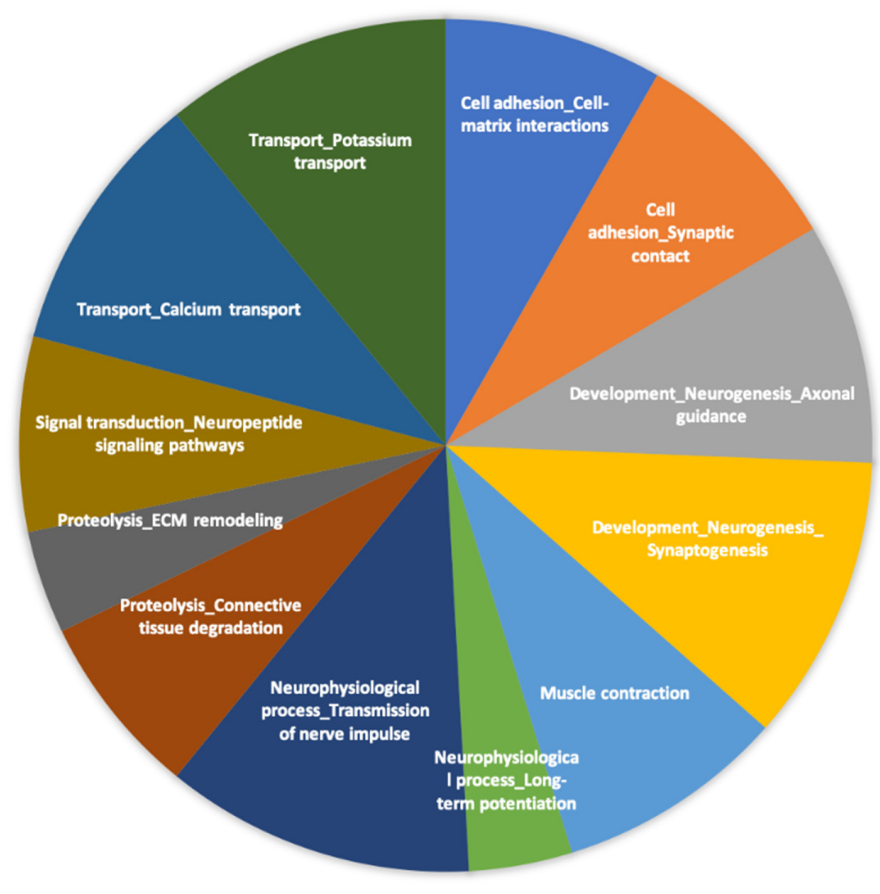

Figure 4. Networks enriched with differentially expressed genes in volunteers' peripheral blood mononuclear cells in response to Passiflora setacea pulp consumption. Gene networks were identified using MecaCore software that uses text mining approach to build gene-gene interactions and identify their cellular functions.

Besides the network analyses, we also performed gene pathway analyses employing the use of the Genetrial2 online tool by searching the KEGG and BioCarta databases. As shown in Figure 5, the differentially expressed genes identified are involved in cellular pathways including inflammation, metabolism, cell signaling, and neurofunction-related processes. Regarding the pathway related to inflammation, we identified a cytokine-cytokine receptor, cell adhesion molecules, and chemokine signaling pathways, 
which include genes such as TNFSF18, IL36A, JAM2, ADCY8, or CCL16. In pathways related to cellular metabolism, we identified circadian entrainment, insulin secretion, and $P 13 K-A k t$ signaling pathways, which include genes such as GRIN2A, PRKG1, CACNA1D, GLP1R, G6PC2, and LAMA1. Calcium and adrenergic signaling pathways were also identified, containing PTGER3, ADCY8, and CACNA1D genes. Several pathways related to neurofunction were also identified such as glutamatergic synapse, neuroactive ligand-receptor interaction, and $M A P K$ signaling pathways, in which genes such as GABRG1; glutamate receptor, ionotropic, NMDA1 (GRIN1); CACNA1D; and ADCY8 were mapped.

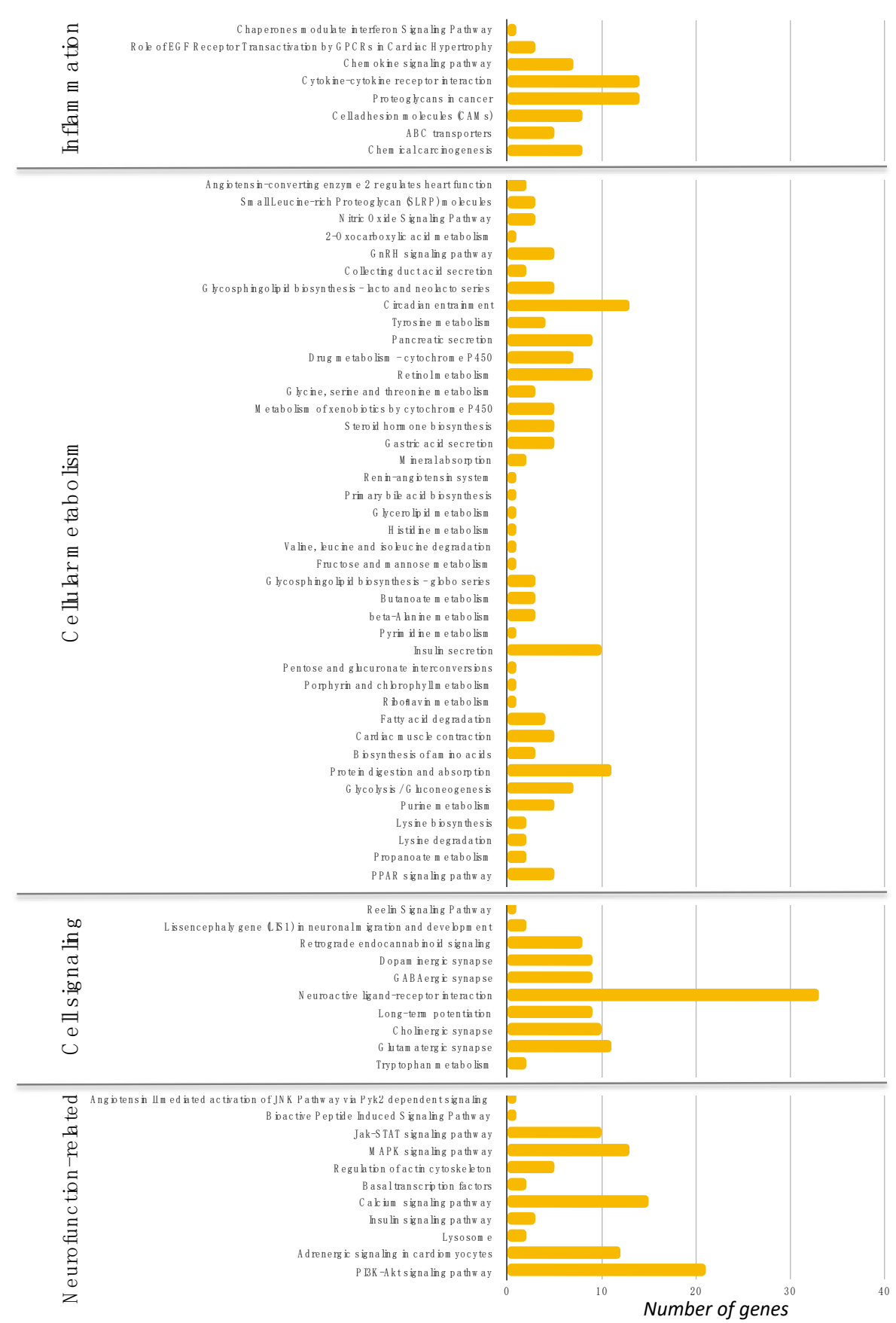

Figure 5. Significantly enriched pathways with differentially expressed genes in volunteers' PBMC in response to PS pulp consumption. Pathways were identified using Genetrial2 online tool and KEGG database, and were grouped regarding their functions. $x$-axis represents the number of genes in each pathway. 


\subsection{Protein-Protein Interaction (Phase 2)}

Apart from the bioinformatics analyses on cellular networks and pathways of differentially expressed genes identified, we also searched for protein-protein interactions. We observed interactions among the genes whose expression were affected by the consumption of PS. By using the online String database, we identified 1013 nodes and 3066 edges with 6.05 nodes on average (Figure S2). Among them, 39 genes showed over 15 interactions with other proteins, making them important nodes in the protein-protein interactome. These 39 genes revealed over 700 interactions, which are a fifth of the total number verified. This suggests that changes in the expression of these genes can have an important impact on protein interactome and consequently on cell function. These genes are involved in the cellular pathways regulating processes such as cyclic adenosine monophosphate (cAMP) signaling pathway, nitric oxide signaling pathway, dopaminergic synapse, insulin, or PI3K-Akt signaling pathways. Proteins interacting with these 32 genes have been searched and 256 genes have been identified. Pathway analyses of these genes showed that they are involved in pathways such as the cAMP signaling pathway, PI3K-Akt signaling pathway, Ras/Rap1 (Ras-related protein 1) signaling, insulin secretion, cytokine-cytokine receptor interaction, chemokine signaling pathway, retrograde endocannabinoid signaling, or regulation of actin cytoskeleton.

\subsection{Transcriptional and Post-Transcriptional Regulators of the Nutrigenomic Effect (Phase 2)}

The bioinformatics analyses of gene expression data were further performed with the aim to identify potential transcription factors involved in the mediation of the PS juice nutrigenomic effect observed. The most significant transcription factors (Figure 6) were cAMP Responsive Element Binding Protein 1 (CREB1), nuclear factor-kappa B (Nf-kB), and specificity protein 1 (SP1). These transcription factors are involved in gluconeogenesis regulation, lipid metabolism, and insulin signaling pathways. They are also associated with vascular calcification, pathogenesis of type 2 diabetes (TD2), and diabetic cardiovascular disease. Other transcription factors are Proto-Oncogene C-Jun (c-jun), Signal Transducer And Activator of Transcription 3 (STAT3), and tumor protein P53 (p53).

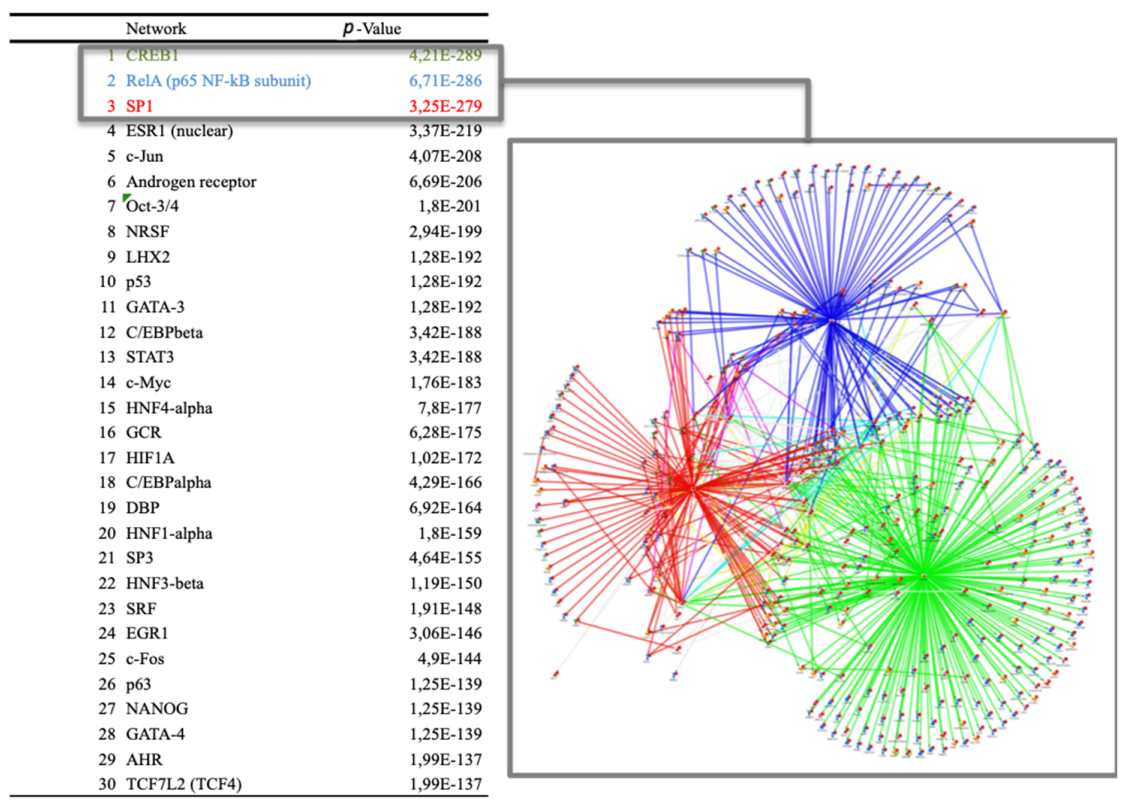

Figure 6. Bioinformatics analyses of potential transcription factors involved in the mediation of the PS juice's nutrigenomic effect observed. Transcription factors were identified using MetaCore algorithm and the most significant transcription factors listed were CAMP Responsive Element Binding Protein 1 (CREB1), nuclear factor-kappa B (Nf-kB), and specificity protein 1 (SP1). On the right, the interactions of the networks with these three transcription factors identified are represented. 
Besides the transcriptional regulators potentially involved in the nutrigenomic effect observed, we also searched for potential post-transcriptional regulators of the gene expression, particularly microRNA. Using the online OmicsNet tool, we identified over 30 microRNAs (miRNAs) that could interact with differentially expressed genes and regulate their expression at the post-transcriptional level (Table 2). This suggests that PS juice consumption could potentially regulate the expression of microRNAs and consequently affect levels of mRNA of genes we identified as differentially expressed. Using the same online tool, we then performed integrated analyses of the identified differentially expressed genes, potential transcription factors, and potential microRNAs (Figure 7). We observed a network of interaction among these three levels of regulation of cell function, suggesting that PS juice consumption can significantly impact immune cells at the molecular level and consequently impact their functions.

Table 2. microRNA list.

\begin{tabular}{cll}
\hline hsa-mir-335-5p & MIMAT0000765 & 228 \\
hsa-mir-26b-5p & MIMAT0000083 & 193 \\
hsa-mir-16-5p & MIMAT0000069 & 161 \\
hsa-mir-92a-3p & MIMAT0000092 & 161 \\
hsa-mir-124-3p & MIMAT0000422 & 152 \\
hsa-mir-155-5p & MIMAT0000093 & 116 \\
hsa-mir-93-5p & MIMAT0000646 & 116 \\
hsa-mir-1-3p & MIMAT0000416 & 114 \\
hsa-mir-17-5p & MIMAT0000070 & 113 \\
hsa-mir-615-3p & MIMAT0003283 & 112 \\
hsa-let-7b-5p & MIMAT0000063 & 104 \\
hsa-mir-106b-5p & MIMAT0000680 & 101 \\
hsa-mir-20a-5p & MIMAT0000075 & 99 \\
hsa-mir-218-5p & MIMAT0000275 & 99 \\
hsa-mir-1-1 & MI0000651 & 98 \\
hsa-mir-484 & MIMAT0002174 & 90 \\
hsa-mir-193b-3p & MIMAT0002819 & 89 \\
hsa-mir-15b-5p & MIMAT0000417 & 88 \\
hsa-mir-15a-5p & MIMAT0000068 & 81 \\
hsa-mir-20b-5p & MIMAT0000076 & 80 \\
hsa-mir-21-5p & MIMAT0001413 & 80 \\
hsa-mir-30a-5p & MIMAT0000087 & 79 \\
hsa-mir-186-5p & MIMAT0000456 & 78 \\
hsa-mir-519d-3p & MIMAT0002853 & 77 \\
hsa-mir-24-3p & MIMAT0000080 & 76 \\
hsa-mir-320a & MIMAT0000510 & 75 \\
hsa-mir-8485 & MIMAT0033692 & 75 \\
hsa-mir-192-5p & MIMAT0000222 & 74 \\
hsa-mir-195-5p & MIMAT0000461 & 73 \\
\hline & & \\
& & \\
\hline
\end{tabular}

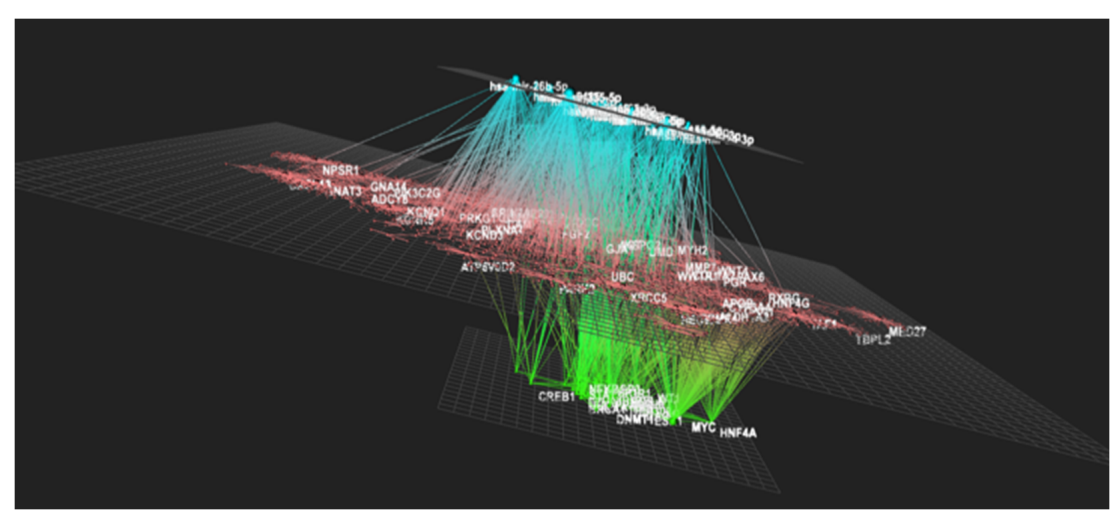

Figure 7. Bioinformatics analyses of potential miRNA involved in the mediation of the Passiflora setacea juice's nutrigenomic effect observed. OmicsNet online tool was used to identify interactions between the differentially expressed genes identified (in pink) with the potential transcription factors identified (in green), and potential miRNAs involved (in blue). 


\section{Discussion}

This is the first time that the effect of a Brazilian savannah fruit was described on IL-17A blood levels and on gene expression profile in humans. We found that the consumption of one serving of PS juice (similar composition of a whole fruit but without its seeds) statistically decreased the levels of insulin and HOMA IR while increasing HDL levels.

It is known that disorders in insulin metabolism and consequently in glucose metabolism result in oxidative stress and inflammation, which lead to micro- and macrovascular dysfunctions and to the further development of diabetes and cardiovascular diseases [5]. These complications are associated with endothelial dysfunction, pro-inflammatory cytokines, reactive oxygen species formation, and adhesion molecule production [32]. This process results in the increase in the adhesion of immune cells to endothelial cells, as well as in their transendothelial migration into the vascular wall, which are the initial steps to the development of atherosclerosis, the origin of all vascular-related diseases. Therefore, by changing the insulin, HOMA IR, and HDL levels, PS juice could exert anti-inflammatory and vasculo-protective properties and consequently prevent or delay the onset of associated diseases. This observation could be related to the results of other in vivo and in vitro studies that have shown the potential of dietary polyphenols on insulin response. For example, isoorientin, a flavonoid found in PS, has proven to revert insulin resistance in adipocytes by stimulating the proper phosphorylation of proteins in the insulin signaling pathway [33]. Another path of action may be explained by the inhibition of the key enzymes involved in starch digestion (alpha-amylase and alpha-glucosidase) by polyphenols [34]. The caffeic acid, a phenolic acid also present in PS has shown the capacity to inhibit these enzymes [35]. Polyphenols from water chestnut husk [36], green tea [37], and apple [38] have been reported to reduce serum insulin levels in normal mice. However, few studies have also shown the effect of whole food on human insulin metabolism. Nyambe-Silavwe and Williamson [39] reported the effect of dried fruits with green tea in the decrease of insulin serum levels in healthy volunteers.

We also observed an increase of blood HDL concentrations after PS juice intake that was not detected within the PB condition. Recent nutrition intervention studies on polyphenol-rich foods such as olive oil [40] or dark chocolate [41] have been shown to positively affect HDL levels in humans. One possible explanation is that these polyphenol-rich foods may induce changes in the biochemical properties of the lipoprotein that contribute to its main biological function, particularly in the enhancement of the cholesterol efflux capacity [42]. It can therefore be suggested that PS consumption modulates risk factors of cardiometabolic diseases.

This study also revealed that an acute intake of PS juice kept IL-17A at a basal level and indicated a tendency to decrease TNF-alpha levels $(p=0.0645)$ when compared to PB condition. The IL-17A is a pro-inflammatory cytokine that stimulates neutrophil inflammatory response [43] and the production of other pro-inflammatory cytokines such as TNF-alpha, IL-1B, and IL-6 [44], as well as the expression of adhesion molecules such as Intercellular Adhesion Molecule 1 (ICAM-1) [45]. Its activities are vastly increased due to synergy with TNF-alpha that promotes the induction of target genes involved in inflammatory processes [46]. Cyanidin, a key flavonoid present in red berries, has shown the capacity to reduce inflammation in mice through binding with the extracellular domain of IL-17RA and consequently disrupting the IL-17A/IL-17RA complex formation [47]. Few studies have provided evidence regarding the role of diet in modulating IL-17 levels in humans. Peluso et al. [6] observed a drop of this cytokine in the plasma of 14 overweight subjects after a pineapple, blackcurrant, and plum juice consumption. Taken together, this observation suggests that PS consumption could present anti-inflammatory effects during the post-prandial period.

In the present study, using microarray analysis, we showed that the consumption of one single cup of PS juice by volunteers significantly affected PBMC gene expression profiles. Our study is the first to show the effect of a Passiflora species on the modulation of gene expression in humans. Another study has shown the capacity of another species of Passiflora in modulating gene expression in mice. Toda et al. [48] demonstrated that the aerial parts of the Passiflora incarnata Linnaeus extract 
can modulate the expression of genes that may be involved in the prevention of obesity [49] and hyperglycemia [50]. Regarding the effects of BC found in PS on gene expression, it has been reported that isoorientin stimulated the transcription of genes encoding components of insulin signaling pathway in murine insulin-sensitive and insulin-resistant adipocytes [33]. Orientin from Commelina communis L. down-regulated the expression of peroxisome proliferator activated receptor (PPAR) and mRNA levels of genes involved in adipogenesis, lipogenesis, and triglyceride sysnthesis in vitro [51]. A plant extract rich in orientin, isoorientin, vitexin, and isovitexin has been shown to inhibit the mRNA levels of TNF- $\alpha$ also in vitro [52]. Therefore, our original study suggests that potential health benefits of PS could be related to its capacity to modulate the expression of genes in vivo in humans.

Bioinformatic analysis also revealed that PS consumption modulated the expression of a group of genes, 25, involved in the regulation of inflammation and immune response, particularly chemokine signaling pathway and cytokine-cytokine receptor interactions. Among these genes are CXCL17, IL36A, CCL16, CCL21, and IL-25. CCL16 is a pro-inflammatory chemokine that may be involved in the development of diseases such as irritable bowel syndrome [53]. Chemokines, a group of cytokines that attract and activate leucocytes into inflamed tissue, have been associated with the pathogenesis of a number of diseases, ranging from atherosclerosis to human immunodeficiency virus (HIV) infection [54], and CCL21 has been suggested as being involved in the pathogenesis of various inflammatory disorders including rheumatoid arthritis, inflammatory bowel diseases, and atherosclerosis [55]. Nutrigenomic analysis also identified several interleukins such as IL-36A that have pro-inflammatory properties and have been described as being involved in pulmonary inflammatory responses [56]. Several studies have shown that foods rich in BC or isolated BC such as hesperidin can regulate the expression of chemokines [7]. Taken together, the results suggest that the acute consumption of PS can present anti-inflammatory effects by modulating the expression of related genes.

This nutrigenomic study identified changes in the expression of genes involved in processes such as cell adhesion and cell-matrix interactions; chemokine signaling; insulin secretion; calcium and potassium transport; as well as inflammation, atherosclerosis development, and neurostimulation. Among them are genes encoding matrix metalloproteinases (MMPs), desintegrins, and metalloproteases (ADAMs), for which expression was identified as down-regulated. MMPs constitute a family of extracellular processing enzymes responsible for inflammation and acquired immunity [57]. Expression of genes encoding MMPs is frequently increased by cytokines, and reactive oxygen species are often involved in this mechanism [58]. MMP-7 over-expression regulates chemokine gradients that can lead to severe tissue damage through transepithelial influx of neutrophils [59]. In an in vitro and in vivo study, resveratrol reversed the injury of human epithelial cells and attenuated such injury in mice through the inhibition of MMP-7 expression [60]. Kinase Insert Domain Receptor (KDR) (or Vascular Endothelial Growth Factor Receptor-2, VEGFR2) is a key receptor that promotes Vascular Endothelial Growth Factor (VEGF) to form mitosis and generate vascularization. VEGF promotes proliferation and migration of cells and activates matrix matalloproteinase secretion [61], which can lead to exacerbation of tissue damage during inflammation. VEGF is highly expressed in tissues undergoing growth or remodeling in cancer and atherosclerosis [62]. KDR's expression was down-regulated with PS juice consumption, as well as JAM-2's (junctional adhesion molecule 2) gene involved in leukocyte recruitment and extravasation under inflammatory conditions [52]. Few studies have suggested the capacity of foods or BC to modulate the expression of these genes. A formulation of Chinese herbs was capable of downregulating the expression of KDR and VEGF in a mouse with hepatocellular carcinoma [63]. Monfoulet et al. [64] revealed the capacity of curcumin to reduce endothelial junctional permeability. Thus, the capacity of PS to down-regulate the expression of this gene suggests a potential lower interaction of immune cells with vascular endothelial cells, which represent the initial steps of atherosclerosis development. As atherosclerosis is associated with the genesis of others cardiovascular diseases, PS juice consumption may reveal interesting mechanisms underlying its potential vasculo-protective properties. 
ADAMs constitute a family of proteases with cell adhesive potential [65] and other functions, including extracellular matrix (ECM) degradation, shedding of various cell surface proteins, and influence on cell signaling patterns [66]. ADAM12 is an active protease in ECM that causes changes in proliferation and differentiation of adipocyte maturation and also in the development of obesity induced by high-fat diet [67]. It has been shown to affect the insulin-like growth factor (IGF)/mTOR (mammalian target of rapamycin) and peroxisome proliferator-activated receptor gamma (PPAR $\gamma$ ) signaling pathways, leading to increased lipid accumulation in mature adipocytes [68]. ADAMTS9 is a risk gene for type 2 diabetes development and its over-expression is associated with impaired insulin signaling in peripheral tissues and also with insulin resistance [69]. Its risk allele (rs4607103 C) has been demonstrated to decrease mitochondrial function and to alter glucose and lipid metabolism [70]. Another gene identified as differentially expressed after PS juice consumption is adenylate cyclase 8 (ADCY8), which is involved in insulin secretion and glucose homeostasis. Sung et al. [71], in a genome-wide association analysis, associated the ADCY8 gene with obesity and abdominal visceral fat depot. Considering all these previous factors, the gene expression profile obtained after an acute consumption of PS suggests a lower accumulation of lipids in PBMCs and a lower impairment in insulin signaling, presenting potential molecular targets of PS juice consumption and their potential health properties.

Besides the modulation of genes related to cardiometabolic regulations, our nutrigenomic analysis also identified the fact that several genes modulated by the acute consumption of PS were associated with neurofunction, such as CACNA1C, GRIN1, and G protein-coupled receptor 50 (GPR50). The immune-to-brain and brain-to-immune communication has been recently studied [72]. The central nervous system can communicate with peripheral monocytes, promoting gene expression modulation, particularly with regards to the NF-kB transcriptional control pathway [73]. The CACNA1C is a gene contributes to the etiology of psychiatric disorders and to phenotypes affected by those conditions such as memory and circadian rhythms [74]. Such symptoms are present in a proportion of the general population and are correlated with poorer cognitive performance and with adverse health outcomes [75] such as atherosclerosis [76]. The GRIN1 (glutamate receptor, ionotropic, NMDA1) gene plays an important role in excitatory neurotransmission, and the increase of its expression has been associated with anxiety in response to stress in mice [77]. Another gene whose expression has been modulated after PS juice consumption was GPR50, a gene involved in late-life depression in certain subgroups of depressed individuals [78]; its down-regulation is associated with torpor enhancement [79]. Acute consumption of PS juice decreased the expression of these genes, which suggests that PS consumption may affect torpor, a hypothesis that can explain PS's popular name "sleep passionfruit". These observations suggest the potential effect of PS consumption as an auxiliary treatment for cognitive functions and for psychiatric disorders.

The three major transcription factors whose activities might be affected by PS consumption and that are possibly involved in the nutrigenomic effect observed are CREB1, RELA Proto-Oncogene (RelA), and SP1. CREB1 regulates gluconeogenesis, lipid metabolism, and insulin signaling pathways, and the activity of its transcriptional promoter is associated with the pathogenesis of TD2 [80], adipogenesis [81], and major depressive disorder [82]. RelA is a sub-unit of NF- $\mathrm{kB}$, a transcription factor critical for the expression of proinflammatory cytokines in human monocytes. Studies on the effect of bioactive compounds (BC) on this transcription factor showed that orientin, isoorientin, vitexin, and isovitexin exert suppressive action of these compounds upon NF-kB activation [24]. Elevated SP1 plays a pro-apoptotic effect and stimulates vascular calcification [83]. It has been observed that the BC (-)-epigallocatechin-3-gallate can modulate the activity of this transcription factor [84]. Therefore, the capacity of PS juice consumption to affect the activity of these transcription factors could present major regulatory mechanisms observed in nutrigenomic modifications underlying their health properties.

Literature lacks data about the effect of Passiflora on miRNA expression. However, it has been suggested that plant food bioactives can modulate the expression of miRNA [85,86]. Among the 
miRNA identified from bioinformatic analysis as potentially involved in the post-transcriptional regulation of identified differentially expressed genes by PS juice consumption, we can list miRNA-16, -26, and -124. miRNA-16 has shown to play a role in inflammation [87] and hypertension [88], whereas miRNA-124 mediates anti-inflammatory effects and is involved in neuroprotective mechanisms [89]. Therefore, by potentially modulating the expression of these miRNAs, PS consumption can regulate genes involved in the development or the prevention of cardiometabolic and neurological diseases.

\section{Conclusions}

This acute study has provided the first clinical data supporting an interest in PS pulp consumption for human health. The positive changes we observed in some inflammatory and metabolic biomarkers as well as in the PBMC gene expression profile after an acute intake of one serving of PS pulp by overweight, middle-age volunteers suggest potential anti-inflammatory and anti-diabetic effects. These results, originating from an acute study, cannot be directly extrapolated to chronic consumption of PS pulp. However, it opens interesting perspectives for future long-term clinical studies using PS products in order to better characterize their health properties and identify the compounds/components responsible for these biological effects. Furthermore, developing this research line is important to increase knowledge on the role of plant foods derived from Brazilian biodiversity in the prevention or delay of the onset of chronic diseases.

Supplementary Materials: The following are available online at http://www.mdpi.com/2072-6643/12/4/1104/s1: List S1: Placebo ingredients. Table S1: "White meal" menu.

Author Contributions: Conceptualization, A.M.C., I.d.A.E.D., D.M., C.M., T.K.d.S.B., and L.d.L.d.O.; methodology, A.M.C., I.d.A.E.D., D.M., C.M., and T.K.d.S.B.; software, D.M. and I.d.A.E.D.; validation, I.d.A.E.D., A.M.C., D.M., A.J.d.M.R., and T.K.d.S.B.; formal analysis, I.d.A.E.D., A.M.C., D.M., and T.K.d.S.B.; investigation, I.d.A.E.D., A.M.C., D.M., T.K.d.S.B., and A.J.d.M.R.; resources, A.M.C.; T.K.d.S.B., and L.d.L.d.O.; data curation, I.d.A.E.D., A.M.C., D.M., and T.K.d.S.B.; writing-original draft preparation, I.d.A.E.D. and D.M.; writing-review and editing, I.d.A.E.D., A.M.C., D.M., T.K.d.S.B., L.d.L.d.O., A.J.d.M.R., and C.M.; visualization, I.d.A.E.D. and D.M.; supervision, A.M.C. and I.d.A.E.D.; project administration, A.M.C., I.d.A.E.D., T.K.d.S.B., and L.d.L.d.O.; funding acquisition, A.M.C. All authors have read and agreed to the published version of the manuscript.

Funding: This research was financed in part by Conselho Nacional de Desenvolvimento Científico e Tecnológico-Brasil (CNPq) and Coordenação de Aperfeiçoamento de Pessoal de Nível Superior-Brasil (CAPES), Finance Code 001.

Acknowledgments: We are indebted to all the subjects who volunteered in the clinical trial. We also thank the team from Sabin Laboratory for the biochemical analyses. We thank Calliandra Maria de Souza Silva for technical assistance for RNA extraction and Celine Boby for microarray experiment technical assistance at the Institut National de la Recherche Agronomique (INRA) "Metabolism Exploration Platform: from genes to metabolites". We also thank Decanato de Pesquisa e Inovação (DPI) and Decanato de Pós-graduação (DPG) from University of Brasilia for the resources for publishing this paper.

Conflicts of Interest: The authors declare no conflict of interest.

\section{References}

1. WHO, W.H.O. Noncommunicable Diseases. Available online: http://www.who.int/news-room/fact-sheets/ detail/noncommunicable-diseases (accessed on 16 September 2018).

2. World Health Organization. Depression and Other Common Mental Disorders: Glocal Health Estimates; World Health Organization: Geneva, Switzerland, 2017.

3. Melaku, Y.A.; Renzaho, A.; Gill, T.K.; Taylor, A.W.; Dal Grande, E.; de Courten, B.; Baye, E.; Gonzalez-Chica, D.; Hyppönen, E.; Shi, Z.; et al. Burden and trend of diet-related non-communicable diseases in Australia and comparison with 34 OECD countries, 1990-2015: Findings from the Global Burden of Disease Study 2015. Eur. J. Nutr. 2018, 58, 1299-1313. [CrossRef] [PubMed]

4. Koolhaas, C.M.; Dhana, K.; Schoufour, J.D.; Ikram, M.A.; Kavousi, M.; Franco, O.H. Impact of physical activity on the association of overweight and obesity with cardiovascular disease: The Rotterdam Study. Eur. J. Prev. Cardiol. 2017, 24, 934-941. [CrossRef] [PubMed] 
5. Pereira, C.A.; Carneiro, F.S.; Matsumoto, T.; Tostes, R.C. Bonus Effects of Antidiabetic Drugs: Possible Beneficial Effects on Endothelial Dysfunction, Vascular Inflammation and Atherosclerosis. Basic Clin. Pharmacol. Toxicol. 2018. [CrossRef] [PubMed]

6. Peluso, I.; Raguzzini, A.; V Villano, D.; Cesqui, E.; Toti, E.; Catasta, G.; Serafini, M. High Fat Meal Increase of IL-17 is Prevented by Ingestion of Fruit Juice Drink in Healthy Overweight Subjects. Curr. Pharm. Des. 2012, 18, 85-90. [CrossRef]

7. Milenkovic, D.; Deval, C.; Dubray, C.; Mazur, A.; Morand, C. Hesperidin Displays Relevant Role in the Nutrigenomic Effect of Orange Juice on Blood Leukocytes in Human Volunteers: A Randomized Controlled Cross-Over Study. PLoS ONE 2011, 6, e26669. [CrossRef]

8. Klöting, N.; Blüher, M. Adipocyte dysfunction, inflammation and metabolic syndrome. Rev. Endocr. Metab. Disord. 2014, 15, 277-287. [CrossRef]

9. Wang, X.; Ouyang, Y.; Liu, J.; Zhu, M.; Zhao, G.; Bao, W.; Hu, F.B. Fruit and vegetable consumption and mortality from all causes, cardiovascular disease, and cancer: Systematic review and dose-response meta-analysis of prospective cohort studies. BMJ 2014, 349, g4490. [CrossRef]

10. Del Rio, D.; Rodriguez-Mateos, A.; Spencer, J.P.E.; Tognolini, M.; Borges, G.; Crozier, A. Dietary (Poly)phenolics in Human Health: Structures, Bioavailability, and Evidence of Protective Effects Against Chronic Diseases. Antioxid. Redox Signal. 2013, 18, 1818-1892. [CrossRef]

11. Denny, A.; Buttriss, J. Plant. Foods and Health: Focus on Plant Bioactives: Synthesis Report no. 4; European Food Information Resource Consortium (EuroFIR): Norwich, UK, 2007; ISBN 978-0-907667-62-9.

12. Muñoz-Esparza, N.C.; Latorre-Moratalla, M.L.; Comas-Basté, O.; Toro-Funes, N.; Veciana-Nogués, M.T.; Vidal-Carou, M.C. Polyamines in Food. Front. Nutr. 2019, 6, 108. [CrossRef]

13. Turati, F.; Rossi, M.; Pelucchi, C.; Levi, F.; La Vecchia, C. Fruit and vegetables and cancer risk: A review of southern European studies. Br. J. Nutr. 2015, 113, S102-S110. [CrossRef]

14. Barber-Chamoux, N.; Milenkovic, D.; Verny, M.-A.; Habauzit, V.; Pereira, B.; Lambert, C.; Richard, D.; Boby, C.; Mazur, A.; Lusson, J.R.; et al. Substantial Variability Across Individuals in the Vascular and Nutrigenomic Response to an Acute Intake of Curcumin: A Randomized Controlled Trial. Mol. Nutr. Food Res. 2018, 62, 1700418. [CrossRef]

15. Dhawan, K.; Dhawan, S.; Sharma, A. Passiflora: A review update. J. Ethnopharmacol. 2004, 94, 1-23. [CrossRef] [PubMed]

16. Appel, K.; Rose, T.; Fiebich, B.; Kammler, T.; Hoffmann, C.; Weiss, G. Modulation of the $\gamma$-aminobutyric acid (GABA) system by Passiflora incarnata L. Phytother. Res. 2011, 25, 838-843. [CrossRef]

17. Bomtempo, L.L.; Costa, A.M.; Lima, H.; Engeseth, N.; Gloria, M.B.A. Bioactive amines in Passiflora are affected by species and fruit development. Food Res. Int. 2016, 89, 733-738. [CrossRef] [PubMed]

18. Gomes, S.V.F.; Portugal, L.A.; dos Anjos, J.P.; de Jesus, O.N.; de Oliveira, E.J.; David, J.P.; David, J.M. Accelerated solvent extraction of phenolic compounds exploiting a Box-Behnken design and quantification of five flavonoids by HPLC-DAD in Passiflora species. Microchem. J. 2017, 132, 28-35. [CrossRef]

19. De Carvalho, M.V.O.; de Oliveira, L.; Costa, A.M. Effect of training system and climate conditions on phytochemicals of Passiflora setacea, a wild Passiflora from Brazilian savannah. Food Chem. 2018, 266, 350-358. [CrossRef]

20. De Santana, F.C.; Shinagawa, F.B.; Araujo, E.; Costa, A.M.; Mancini-Filho, J. Chemical Composition and Antioxidant Capacity of Brazilian Passiflora Seed Oils. J. Food Sci. 2015, 80, C2647-C2654. [CrossRef]

21. Santana, F.C. de Evaluation of bioactive compounds present in Passiflora spp. seed and its influence on oxidative stress and inflammation in a high fat-fed mice. Ph.D. Thesis, University of São Paulo, São Paulo, Brazil, 2015.

22. Wang, C.; Xu, F.-Q.; Shang, J.-H.; Xiao, H.; Fan, W.-W.; Dong, F.-W.; Hu, J.-M.; Zhou, J. Cycloartane triterpenoid saponins from water soluble of Passiflora edulis Sims and their antidepressant-like effects. J. Ethnopharmacol. 2013, 148, 812-817. [CrossRef]

23. Ku, S.-K.; Kwak, S.; Bae, J.-S. Orientin Inhibits High Glucose-Induced Vascular Inflammation In Vitro and In Vivo. Inflammation 2014, 37, 2164-2173. [CrossRef]

24. Lee, W.; Ku, S.-K.; Bae, J.-S. Vascular barrier protective effects of orientin and isoorientin in LPS-induced inflammation in vitro and in vivo. Vasc. Pharmacol. 2014, 62, 3-14. [CrossRef] 
25. Muhammad, T.; Ikram, M.; Ullah, R.; Rehman, S.; Kim, M. Hesperetin, a Citrus Flavonoid, Attenuates LPS-Induced Neuroinflammation, Apoptosis and Memory Impairments by Modulating TLR4/NF- $\mathrm{B}$ Signaling. Nutrients 2019, 11, 648. [CrossRef] [PubMed]

26. Soulimani, R.; Younos, C.; Jarmouni, S.; Bousta, D.; Misslin, R.; Mortier, F. Behavioural effects of Passiflora incarnata L. and its indole alkaloid and flavonoid derivatives and maltol in the mouse. J. Ethnopharmacol. 1997, 57, 11-20. [CrossRef]

27. Turner-McGrievy, G.M.; Wirth, M.D.; Shivappa, N.; Wingard, E.E.; Fayad, R.; Wilcox, S.; Frongillo, E.A.; Hébert, J.R. Randomization to plant-based dietary approaches leads to larger short-term improvements in Dietary Inflammatory Index scores and macronutrient intake compared with diets that contain meat. Nutr. Res. 2015, 35, 97-106. [CrossRef] [PubMed]

28. Satija, A.; Bhupathiraju, S.N.; Spiegelman, D.; Chiuve, S.E.; Manson, J.E.; Willett, W.; Rexrode, K.M.; Rimm, E.B.; Hu, F.B. Healthful and Unhealthful Plant-Based Diets and the Risk of Coronary Heart Disease in U.S. Adults. J. Am. Coll. Cardiol. 2017, 70, 411-422. [CrossRef]

29. Zhao, C.-N.; Meng, X.; Li, Y.; Li, S.; Liu, Q.; Tang, G.-Y.; Li, H.-B. Fruits for Prevention and Treatment of Cardiovascular Diseases. Nutrients 2017, 9, 598. [CrossRef]

30. Da Rocha, P.E.C.P. Medidas e Avaliação em Ciências do Esporte, 4th ed.; Sprint: Rio de Janeiro, Brazil, 2000; ISBN 85-85031-87-5.

31. Allain, C.C.; Poon, L.S.; Chan, C.S.; Richmond, W.; Fu, P.C. Enzymatic determination of total serum cholesterol. Clin. Chem. 1974, 20, 470-475. [CrossRef]

32. Shah, M.S.; Brownlee, M. Molecular and Cellular Mechanisms of Cardiovascular Disorders in Diabetes. Circ. Res. 2016, 118, 1808-1829. [CrossRef]

33. Alonso-Castro, A.J.; Zapata-Bustos, R.; Gómez-Espinoza, G.; Salazar-Olivo, L.A. Isoorientin Reverts TNF- $\alpha$-Induced Insulin Resistance in Adipocytes Activating the Insulin Signaling Pathway. Endocrinology 2012, 153, 5222-5230. [CrossRef]

34. Sun, L.; Miao, M. Dietary polyphenols modulate starch digestion and glycaemic level: A review. Crit. Rev. Food Sci. Nutr. 2019, 1-15. [CrossRef]

35. Sun, L.; Chen, W.; Meng, Y.; Yang, X.; Yuan, L.; Guo, Y. Interactions between polyphenols in thinned young apples and porcine pancreatic $\alpha$-amylase: Inhibition, detailed kinetics and fluorescence quenching. Food Chem. 2016, 208, 51-60. [CrossRef]

36. Yasuda, M.; Yasutake, K.; Hino, M.; Ohwatari, H.; Ohmagari, N.; Takedomi, K.; Tanaka, T.; Nonaka, G. Inhibitory effects of polyphenols from water chestnut (Trapa japonica) husk on glycolytic enzymes and postprandial blood glucose elevation in mice. Food Chem. 2014, 165, 42-49. [CrossRef] [PubMed]

37. Forester, S.C.; Gu, Y.; Lambert, J.D. Inhibition of starch digestion by the green tea polyphenol, (-)-epigallocatechin-3-gallate. Mol. Nutr. Food Res. 2012, 56, 1647-1654. [CrossRef] [PubMed]

38. Shin, S.-K.; Cho, S.-J.; Jung, U.; Ryu, R.; Choi, M.-S. Phlorizin Supplementation Attenuates Obesity, Inflammation, and Hyperglycemia in Diet-Induced Obese Mice Fed a High-Fat Diet. Nutrients 2016, 8, 92. [CrossRef]

39. Nyambe-Silavwe, H.; Williamson, G. Polyphenol- and fibre-rich dried fruits with green tea attenuate starch-derived postprandial blood glucose and insulin: A randomised, controlled, single-blind, cross-over intervention. Br. J. Nutr. 2016, 116, 443-450. [CrossRef] [PubMed]

40. Sanchez-Rodriguez, E.; Lima-Cabello, E.; Biel-Glesson, S.; Fernandez-Navarro, J.; Calleja, M.; Roca, M.; Espejo-Calvo, J.; Gil-Extremera, B.; Soria-Florido, M.; de la Torre, R.; et al. Effects of Virgin Olive Oils Differing in Their Bioactive Compound Contents on Metabolic Syndrome and Endothelial Functional Risk Biomarkers in Healthy Adults: A Randomized Double-Blind Controlled Trial. Nutrients 2018, 10, 626. [CrossRef] [PubMed]

41. Petrilli, A.; Souza, S.; Teixeira, A.; Pontilho, P.; Souza, J.; Luzia, L.; Rondó, P. Effect of Chocolate and Yerba Mate Phenolic Compounds on Inflammatory and Oxidative Biomarkers in HIV/AIDS Individuals. Nutrients 2016, 8, 132. [CrossRef] [PubMed]

42. Hernáez, Á.; Fernández-Castillejo, S.; Farràs, M.; Catalán, Ú.; Subirana, I.; Montes, R.; Solà, R.; Muñoz-Aguayo, D.; Gelabert-Gorgues, A.; Díaz-Gil, Ó.; et al. Olive Oil Polyphenols Enhance High-Density Lipoprotein Function in Humans: A Randomized Controlled Trial. Arterioscler. Thromb. Vasc. Biol. 2014, 34, 2115-2119. [CrossRef] [PubMed] 
43. Lin, A.M.; Rubin, C.J.; Khandpur, R.; Wang, J.Y.; Riblett, M.; Yalavarthi, S.; Villanueva, E.C.; Shah, P.; Kaplan, M.J.; Bruce, A.T. Mast Cells and Neutrophils Release IL-17 through Extracellular Trap Formation in Psoriasis. J. Immunol. 2011, 187, 490-500. [CrossRef] [PubMed]

44. Jovanovic, D.V.; Di Battista, J.A.; Martel-Pelletier, J.; Jolicoeur, F.C.; He, Y.; Zhang, M.; Mineau, F.; Pelletier, J.P. IL-17 stimulates the production and expression of proinflammatory cytokines, IL-beta and TNF-alpha, by human macrophages. J. Immunol. 1998, 160, 3513-3521.

45. Kharwar, N.K.; Prasad, K.N.; Singh, K.; Paliwal, V.K.; Modi, D.R. Polymorphisms of IL-17 and ICAM-1 and their expression in Guillain-Barré syndrome. Int. J. Neurosci. 2017, 127, 680-687. [CrossRef]

46. Bosteen, M.H.; Tritsaris, K.; Hansen, A.J.; Dissing, S. IL-17A potentiates TNF $\alpha$-induced secretion from human endothelial cells and alters barrier functions controlling neutrophils rights of passage. Pflügers Arch. Eur. J. Physiol. 2014, 466, 961-972. [CrossRef]

47. Liu, C.; Zhu, L.; Fukuda, K.; Ouyang, S.; Chen, X.; Wang, C.; Zhang, C.; Martin, B.; Gu, C.; Qin, L.; et al. The flavonoid cyanidin blocks binding of the cytokine interleukin-17A to the IL-17RA subunit to alleviate inflammation in vivo. Sci. Signal. 2017, 10, eaaf8823. [CrossRef] [PubMed]

48. Toda, K.; Hitoe, S.; Takeda, S.; Shimizu, N.; Shimoda, H. Passionflower Extract Induces High-amplitude Rhythms without Phase Shifts in the Expression of Several Circadian Clock Genes in Vitro and in Vivo. Int. J. Biomed. Sci. 2017, 13, 84-92. [PubMed]

49. Kubo, T.; Fujino, Y.; Nakamura, T.; Kunimoto, M.; Tabata, H.; Tsuchiya, T.; Kadowaki, K.; Odoi, H.; Oyama, I.; Matsuda, S. An Industry-Based Cohort Study of the Association between Weight Gain and Hypertension Risk Among Rotating Shift Workers. J. Occup. Environ. Med. 2013, 55, 1041-1045. [CrossRef] [PubMed]

50. Oyama, I.; Kubo, T.; Fujino, Y.; Kadowaki, K.; Kunimoto, M.; Shirane, K.; Tabata, H.; Sabanai, K.; Nakamura, T.; Matsuda, S. Retrospective cohort study of the risk of impaired glucose tolerance among shift workers. Scand. J. Work. Health 2012, 38, 337-342. [CrossRef] [PubMed]

51. Nagai, S.; Matsumoto, C.; Shibano, M.; Fujimori, K. Suppression of Fatty Acid and Triglyceride Synthesis by the Flavonoid Orientin through Decrease of C/EBP $\delta$ Expression and Inhibition of PI3K/Akt-FOXO1 Signaling in Adipocytes. Nutrients 2018, 10, 130. [CrossRef]

52. Weber, C.; Fraemohs, L.; Dejana, E. The role of junctional adhesion molecules in vascular inflammation. Nat. Rev. Immunol. 2007, 7, 467-477. [CrossRef]

53. Hayatbakhsh, M.M.; Gowhari Shabgah, A.; Pishgouyi, S.; Tavakol Afshari, J.; Zeidabadi, H.; Mohammadi, M. The Serum Levels of CCL2 and CCL16 Expression in Patients with Irritable Bowel Syndrome. Rep. Biochem. Mol. Biol. 2019, 8, 9-14.

54. Charo, I.F.; Ransohoff, R.M. The Many Roles of Chemokines and Chemokine Receptors in Inflammation. New Engl. J. Med. 2006, 354, 610-621. [CrossRef]

55. Fevang, B.; Yndestad, A.; Damås, J.K.; Halvorsen, B.; Holm, A.M.; Beiske, K.; Aukrust, P.; Frøland, S.S. Chemokines and common variable immunodeficiency; possible contribution of CCL19, CCL21 and CCR7 to immune dysregulation. Clin. Exp. Immunol. 2009, 158, 237-245. [CrossRef]

56. Zhang, J.; Yin, Y.; Lin, X.; Yan, X.; Xia, Y.; Zhang, L.; Cao, J. IL-36 induces cytokine IL-6 and chemokine CXCL8 expression in human lung tissue cells: Implications for pulmonary inflammatory responses. Cytokine 2017, 99, 114-123. [CrossRef] [PubMed]

57. Parks, W.C.; Wilson, C.L.; López-Boado, Y.S. Matrix metalloproteinases as modulators of inflammation and innate immunity. Nat. Rev. Immunol. 2004, 4, 617-629. [CrossRef] [PubMed]

58. Halliwell, B.; Gutteridge, J.M.C. Free radicals in biology and medicine, 5th ed.; Oxford University Press: Oxford, UK, 2015; ISBN 978-0-19-871747-8.

59. Swee, M.; Wilson, C.L.; Wang, Y.; McGuire, J.K.; Parks, W.C. Matrix metalloproteinase-7 (matrilysin) controls neutrophil egress by generating chemokine gradients. J. Leukoc. Biol. 2008, 83, 1404-1412. [CrossRef] [PubMed]

60. Xiao, Z.; Chen, C.; Meng, T.; Zhang, W.; Zhou, Q. Resveratrol attenuates renal injury and fibrosis by inhibiting transforming growth factor- $\beta$ pathway on matrix metalloproteinase 7. Exp. Biol. Med. 2016, 241, 140-146. [CrossRef] [PubMed]

61. Unemori, E.N.; Ferrara, N.; Bauer, E.A.; Amento, E.P. Vascular endothelial growth factor induces interstitial collagenase expression in human endothelial cells. J. Cell. Physiol. 1992, 153, 557-562. [CrossRef] [PubMed]

62. Park-Windhol, C.; D'Amore, P.A. Disorders of Vascular Permeability. Annu. Rev. Pathol. Mech. Dis. 2016, 11, 251-281. [CrossRef] [PubMed] 
63. Xinyue, Z.; Shengyan, X.; Yanhui, W.; Yangxinzi, X.; Galia, P.; Yu, S.; Yao, C.; Guanjie, L.; Pei, L. Efficacy of Ciji Hua'ai Baosheng formula on the expressions of vascular endothelial growth factor, kinase insert domain-containing receptor and basic fibroblast growth factor in mouse models of $\mathrm{H} 22$ hepatocellular carcinoma. J. Tradit. Chin. Med. 2017, 37, 88-95. [CrossRef]

64. Monfoulet, L.-E.; Mercier, S.; Bayle, D.; Tamaian, R.; Barber-Chamoux, N.; Morand, C.; Milenkovic, D. Curcumin modulates endothelial permeability and monocyte transendothelial migration by affecting endothelial cell dynamics. Free Radic. Biol. Med. 2017, 112, 109-120. [CrossRef] [PubMed]

65. Giebeler, N.; Zigrino, P. A Disintegrin and Metalloprotease (ADAM): Historical Overview of Their Functions. Toxins 2016, 8, 122. [CrossRef]

66. Hooper, N.M.; Lendeckel, U. (Eds.) The Adam family of proteases; Proteases in biology and disease; Springer: Dordrecht, The Netherlands, 2005; ISBN 978-0-387-25149-3.

67. Masaki, M.; Kurisaki, T.; Shirakawa, K.; Sehara-Fujisawa, A. Role of Meltrin $\alpha$ (ADAM12) in Obesity Induced by High- Fat Diet. Endocrinology 2005, 146, 1752-1763. [CrossRef] [PubMed]

68. Coles, C.A.; Maksimovic, J.; Wadeson, J.; Fahri, F.T.; Webster, T.; Leyton, C.; McDonagh, M.B.; White, J.D. Knockdown of a disintegrin A metalloprotease 12 (ADAM12) during adipogenesis reduces cell numbers, delays differentiation, and increases lipid accumulation in 3T3-L1 cells. Mol. Biol. Cell 2018, 29, 1839-1855. [CrossRef] [PubMed]

69. Zeggini, E.; Scott, L.J.; Saxena, R.; Voight, B.F.; Marchini, J.L.; Hu, T.; de Bakker, P.I.; Abecasis, G.R.; Almgren, P.; Andersen, G.; et al. Meta-analysis of genome-wide association data and large-scale replication identifies additional susceptibility loci for type 2 diabetes. Nat. Genet. 2008, 40, 638-645. [CrossRef] [PubMed]

70. Graae, A.-S.; Grarup, N.; Ribel-Madsen, R.; Lystbæk, S.H.; Boesgaard, T.; Staiger, H.; Fritsche, A.; Wellner, N.; Sulek, K.; Kjolby, M.; et al. ADAMTS9 Regulates Skeletal Muscle Insulin Sensitivity Through Extracellular Matrix Alterations. Diabetes 2019, 68, 502-514. [CrossRef] [PubMed]

71. Sung, Y.J.; Pérusse, L.; Sarzynski, M.A.; Fornage, M.; Sidney, S.; Sternfeld, B.; Rice, T.; Terry, J.G.; Jacobs, D.R.; Katzmarzyk, P.; et al. Genome-wide association studies suggest sex-specific loci associated with abdominal and visceral fat. Int. J. Obes. 2016, 40, 662-674. [CrossRef] [PubMed]

72. Wohleb, E.S.; McKim, D.B.; Sheridan, J.F.; Godbout, J.P. Monocyte trafficking to the brain with stress and inflammation: A novel axis of immune-to-brain communication that influences mood and behavior. Front. Neurosci. 2015, 8. [CrossRef] [PubMed]

73. Miller, G.E.; Chen, E.; Sze, J.; Marin, T.; Arevalo, J.M.G.; Doll, R.; Ma, R.; Cole, S.W. A Functional Genomic Fingerprint of Chronic Stress in Humans: Blunted Glucocorticoid and Increased NF-kB Signaling. Biol. Psychiatry 2008, 64, 266-272. [CrossRef]

74. Heyes, S.; Pratt, W.S.; Rees, E.; Dahimene, S.; Ferron, L.; Owen, M.J.; Dolphin, A.C. Genetic disruption of voltage-gated calcium channels in psychiatric and neurological disorders. Prog. Neurobiol. 2015, 134, 36-54. [CrossRef]

75. McDonald, K.C.; Saunders, K.E.; Geddes, J.R. Sleep problems and suicide associated with mood instability in the Adult Psychiatric Morbidity Survey, 2007. Aust. New Zealand J. Psychiatry 2017, 51, 822-828. [CrossRef]

76. Goldstein, B.I.; Carnethon, M.R.; Matthews, K.A.; McIntyre, R.S.; Miller, G.E.; Raghuveer, G.; Stoney, C.M.; Wasiak, H.; McCrindle, B.W. Major Depressive Disorder and Bipolar Disorder Predispose Youth to Accelerated Atherosclerosis and Early Cardiovascular Disease: A Scientific Statement From the American Heart Association. Circulation 2015, 132, 965-986. [CrossRef]

77. Mozhui, K.; Karlsson, R.M.; Kash, T.L.; Ihne, J.; Norcross, M.; Patel, S.; Farrell, M.R.; Hill, E.E.; Graybeal, C.; Martin, K.P.; et al. Strain Differences in Stress Responsivity Are Associated with Divergent Amygdala Gene Expression and Glutamate-Mediated Neuronal Excitability. J. Neurosci. 2010, 30, 5357-5367. [CrossRef]

78. Ryan, J.; Carrière, I.; Ritchie, K.; Ancelin, M.-L. Involvement of GPR50 polymorphisms in depression: independent replication in a prospective elderly cohort. Brain Behav. 2015, 5, e00313. [CrossRef] [PubMed]

79. Bechtold, D.A.; Sidibe, A.; Saer, B.R.C.; Li, J.; Hand, L.E.; Ivanova, E.A.; Darras, V.M.; Dam, J.; Jockers, R.; Luckman, S.M.; et al. A Role for the Melatonin-Related Receptor GPR50 in Leptin Signaling, Adaptive Thermogenesis, and Torpor. Curr. Biol. 2012, 22, 70-77. [CrossRef] [PubMed]

80. Xu, Y.; Song, R.; Long, W.; Guo, H.; Shi, W.; Yuan, S.; Xu, G.; Zhang, T. CREB1 functional polymorphisms modulating promoter transcriptional activity are associated with type 2 diabetes mellitus risk in Chinese population. Gene 2018, 665, 133-140. [CrossRef] [PubMed] 
81. Ramos-Lopez, O.; Samblas, M.; Milagro, F.I.; Riezu-Boj, J.I.; Crujeiras, A.B.; Martinez, J.A.; Project, M. Circadian gene methylation profiles are associated with obesity, metabolic disturbances and carbohydrate intake. Chronobiol. Int. 2018, 35, 969-981. [CrossRef] [PubMed]

82. Zubenko, G.S.; Hughes, H.B.; Jordan, R.M.; Lyons-Weiler, J.; Cohen, B.M. Differential hippocampal gene expression and pathway analysis in an etiology-based mouse model of major depressive disorder. Am. J. Med Genet. Part B Neuropsychiatr. Genet. 2014, 165, 457-466. [CrossRef] [PubMed]

83. Zhang, X.; Li, R.; Qin, X.; Wang, L.; Xiao, J.; Song, Y.; Sheng, X.; Guo, M.; Ji, X. Sp1 Plays an Important Role in Vascular Calcification Both In Vivo and In Vitro. J. Am. Heart Assoc. 2018, 7. [CrossRef] [PubMed]

84. Fang, C.-Y.; Wu, C.-C.; Hsu, H.-Y.; Chuang, H.-Y.; Huang, S.-Y.; Tsai, C.-H.; Chang, Y.; Tsao, G.; Chen, C.-L.; Chen, J.-Y. EGCG Inhibits Proliferation, Invasiveness and Tumor Growth by Up-Regulation of Adhesion Molecules, Suppression of Gelatinases Activity, and Induction of Apoptosis in Nasopharyngeal Carcinoma Cells. Int. J. Mol. Sci. 2015, 16, 2530-2558. [CrossRef]

85. Milenkovic, D.; Jude, B.; Morand, C. miRNA as molecular target of polyphenols underlying their biological effects. Free Radic. Biol. Med. 2013, 64, 40-51. [CrossRef] [PubMed]

86. Milenkovic, D.; Berghe, W.V.; Morand, C.; Claude, S.; van de Sandt, A.; Gorressen, S.; Monfoulet, L.-E.; Chirumamilla, C.S.; Declerck, K.; Szic, K.S.v.; et al. A systems biology network analysis of nutri(epi)genomic changes in endothelial cells exposed to epicatechin metabolites. Sci. Rep. 2018, 8, 1-17. [CrossRef] [PubMed]

87. Heyn, J.; Ledderose, C.; Hinske, L.C.; Limbeck, E.; Möhnle, P.; Lindner, H.A.; Kreth, S. Adenosine A2A Receptor Upregulation in Human PMNs Is Controlled by miRNA-214, miRNA-15, and miRNA-16. Shock 2012, 37, 156-163. [CrossRef] [PubMed]

88. Fernandes, T.; Magalhães, F.C.; Roque, F.R.; Phillips, M.I.; Oliveira, E.M. Exercise Training Prevents the Microvascular Rarefaction in Hypertension Balancing Angiogenic and Apoptotic Factors: Role of MicroRNAs-16, -21, and -126. Hypertension 2012, 59, 513-520. [CrossRef] [PubMed]

89. Sun, Y.; Luo, Z.-M.; Guo, X.-M.; Su, D.-F.; Liu, X. An updated role of microRNA-124 in central nervous system disorders: a review. Front. Cell. Neurosci. 2015, 9, 193. [CrossRef]

(C) 2020 by the authors. Licensee MDPI, Basel, Switzerland. This article is an open access article distributed under the terms and conditions of the Creative Commons Attribution (CC BY) license (http://creativecommons.org/licenses/by/4.0/). 